\title{
Fatty acids elucidate sub-Antarctic stream benthic food web dynamics invaded by the North American beaver (Castor canadensis)
}

\author{
Christopher B. Anderson ${ }^{1,2} \cdot$ Marina Tagliaferro $^{1} \cdot$ Aaron Fisk $^{3} \cdot$ Amy D. Rosemond $^{4} \cdot$ Marisol L. Sanchez $^{5}$. \\ Michael T. Arts ${ }^{6}$
}

Received: 9 April 2019 / Revised: 3 March 2020 / Accepted: 6 March 2020 / Published online: 13 March 2020

(c) Springer-Verlag GmbH Germany, part of Springer Nature 2020

\begin{abstract}
Despite being remote, polar and sub-polar regions are increasingly threatened by global ecological change. For instance, South America's sub-Antarctic forest ecoregion is considered one of the world's last wilderness areas and a global reference site for pre-Industrial Revolution nutrient cycles. Nonetheless, the North American beaver (Castor canadensis) was introduced to Tierra del Fuego in 1946 and, as an invasive ecosystem engineer, has transformed the ecology of regional watersheds. Beavers' engineering activities transform forested streams (FS) into beaver ponds (BP), where there is greater light and primary production (allochthonous organic matter) and, consequently, increased basal resource quality. To investigate this, we analyzed algal, diatom, fungal and bacterial fatty acid (FA) biomarkers in three basal resource categories (biofilm, very fine benthic organic matter, coarse benthic organic matter) and benthic consumers from four functional feeding groups (FFG). The amphipod Hyalella spp. was chosen as an indicator species due to its abundance and biomass in both habitats. Hyalella spp. had higher proportions of algal and bacterial FA in BP than FS. In FS, Hyalella spp. (gatherer) and Gigantodax spp. (filterer, Diptera) had greater contributions of higher quality FA (higher in polyunsaturated FA), while Rheochorema magallanicum (predator, Trichoptera) and Meridialaris spp. (scraper, Ephemeroptera) showed lower quality monounsaturated and saturated FA. All FFGs showed evidence of microbial FA and had higher levels of autochthonous FA biomarkers than their food resources. Scrapers had the greatest proportion of autochthonous FA. These data provide new insights into the utilization of basal resources by stream consumers in sub-Antarctic streams and how beavers modify these ecosystems.
\end{abstract}

Keywords Basal resources · Benthic macroinvertebrates · Biological invasion · PUFA · Exotic species · Lipid analysis · Patagonia

Marina Tagliaferro

azulmarinita@gmail.com

1 Centro Austral de Investigaciones Científicas (CADIC), Consejo Nacional de Investigaciones Científicas y Técnicas (CONICET), Tierra del Fuego, Houssay 200, 9410 Ushuaia, Argentina

2 Instituto de Ciencias Polares, Ambiente y Recursos Naturales (ICPA), Universidad Nacional de Tierra del Fuego (UNTDF), Tierra del Fuego, Fuegia Basket 251, 9410 Ushuaia, Argentina

3 Great Lakes Institute for Environmental Research, University of Windsor, Windsor N9B 3P4, Canada

4 Odum School of Ecology, University of Georgia, Athens, GA 30602, USA

5 Department of Biological Sciences, University of North Texas, Denton, TX 76203, USA

6 Department of Chemistry and Biology, Ryerson University, Toronto M5B 2K3, Canada

\section{Introduction}

Food web analyses allow the integration of population and community-level parameters for broader ecosystem assessments of energy flow and trophic interactions (Polis and Strong 1996; Polis et al. 2004). However, it is often difficult to link specific components of basal resources with their ultimate origin and fate in food webs. As a result, efforts have been made to use biomarkers and other chemical indicators (e.g., contaminants, essential fatty acids, heavy metals, stable isotopes, etc.) (Arts and Wainman 1999; Vander Zanden et al. 1999; Pollierer et al. 2010; Bierwagen et al. 2019). Traditionally, food web ecology has emphasized energy and material flows and used such methods as the trophic basis of production (TBP, Benke and Wallace 1980) and quantification of elemental flows (Cross et al. 2007), which measure flows of energy, and quantity of carbon, nitrogen 
and phosphorus. However, these techniques alone do not fully elucidate the origin and fate of certain biomolecules or microelements that may be important in animal diets (Volk and Kiffney 2012; Jardine et al. 2015; Guo et al. 2016).

Often, the relative importance of basal food sources has been determined by the quantity of food ingested by consumers, as determined by gut content analyses and direct feeding observations (Lau et al. 2008; Benke 2018). However, differences between what consumers ingest and what is actually assimilated can complicate assessments of trophic status and ecological roles (Whiles et al. 2010). In particular, lipid analyses, including fatty acids (FA), offer a complementary methodology to further enhance our understanding of food web dynamics. Recently, this approach has become more common and less cost-prohibitive, leading to its greater adoption in stream benthic ecosystem research to clarify not only food web relationships, but also drivers of change in these systems (e.g., Larson et al. 2013). Therefore, FA analyses complement and enhance other techniques, such as stable isotopes, gut analyses and TBP, because they provide additional detail and resolution concerning specific food web components.

Numerous natural and human-induced drivers can influence food web dynamics and basal resource quality, including season, land use, and eutrophication (Arts et al. 2009; Kominoski and Rosemond 2012). While Tierra del Fuego's sub-Antarctic ecoregion has largely escaped anthropogenic drivers of global ecological change (e.g., urbanization, eutrophication) and was classified as one of the last "wilderness areas" on the planet (Mittermeier et al. 2003), these watersheds are heavily invaded by the North America beaver (Castor canadensis) (Anderson et al. 2006; Valenzuela et al. 2014). Indeed, today, the sub-Antarctic forest biome has the highest number of invasive terrestrial mammals of any ecoregion in the Southern Cone (Ballari et al. 2015). This biological invasion, as a result, has caused the largest landscape-level alteration of sub-Antarctic streams in the Anthropocene, affecting stream ecosystem structure and function, including impacts to benthic resource quantity and availability (Anderson and Rosemond 2007, 2010; Papier et al. 2019). Beavers are known to increase terrestrially derived organic matter standing crops in Tierra del Fuego (Anderson and Rosemond 2007), but based on data from North America, they potentially enhance phytoplankton as well (Naiman et al. 1986). Thus, these cool low productivity and highly oligotrophic sub-Antarctic forested streams found in the Tierra del Fuego Archipelago (Moorman et al. 2009) are being transformed by invasive beavers (Anderson et al. 2009; Westbrook et al. 2017). In particular, beaver engineering increases the retention of organic matter and decreases substrate diversity, which simultaneously increases benthic secondary production and flows of amorphous detritus, but decreases taxonomic diversity (Anderson and Rosemond
2007). Nonetheless, more detailed information is lacking in southern Patagonia as to how these modifications to resource quantity and quality influence macroinvertebrate ingestion and assimilation of FA and ultimately benthic community dynamics.

Therefore, to complement previous studies in this region and build on what was learned via TBP (Anderson and Rosemond 2010), we conducted a study of FA profiles in the benthic food webs of a natural, forested stream (FS) and a modified beaver pond (BP). Our specific objectives were to better understand the origin, composition and fate of organic matter in impacted sub-Antarctic streams by (i) assessing the FA profiles of benthic basal resources in sites with and without beaver impacts, (ii) determining the FA profiles of four dominant benthic macroinvertebrate taxa, representing each major functional feeding group (FFG), and (iii) comparing the FA profiles of the consumer Hyalella spp. (Amphipoda), which is abundant in both BP and FS. We hypothesized that FA from basal resources in the BP would have more indicators of autochthonous sources than those in the FS. While beavers increase allochthonous material input and retention in the stream, they also expand the surface area of the water body and open the tree canopy, thereby potentially shifting lower order streams to conditions more similar to higher order ones (as per the River Continuum Concept: RCC; Vannote et al. 1980). Therefore, we expected that the resource base and also consumers in the BP would demonstrate a greater reliance on primary producers.

\section{Methods}

\section{Study site}

This study was carried out in the Róbalo River on Navarino Island within Chilean portion of the Tierra del Fuego Archipelago to the south of the Beagle Channel (54 $56.3^{\circ} \mathrm{S}$; $63^{\circ} 37.7^{\prime} \mathrm{W}$; Fig. 1). Field research was conducted in two habitat types: (1) Natural Forest (FS): a stream segment of the Róbalo River not influenced by beavers or humans and whose intact natural riparian forest vegetation was a mix of co-dominant Nothofagus pumilio and N. betuloides, and (2) Beaver Pond (BP): a formerly forested stream segment of the Róbalo River impacted by the direct action of $C$. canadensis, including both damming and foraging of the adjacent riparian mixed forest. FS was located $\sim 1 \mathrm{~km}$ downstream from BP. For more detailed site descriptions see Anderson and Rosemond (2007, 2010).

\section{Sample collection and laboratory analysis}

Benthic basal resource and macroinvertebrate samples were taken in the austral summer of 2003. Five replicates were 


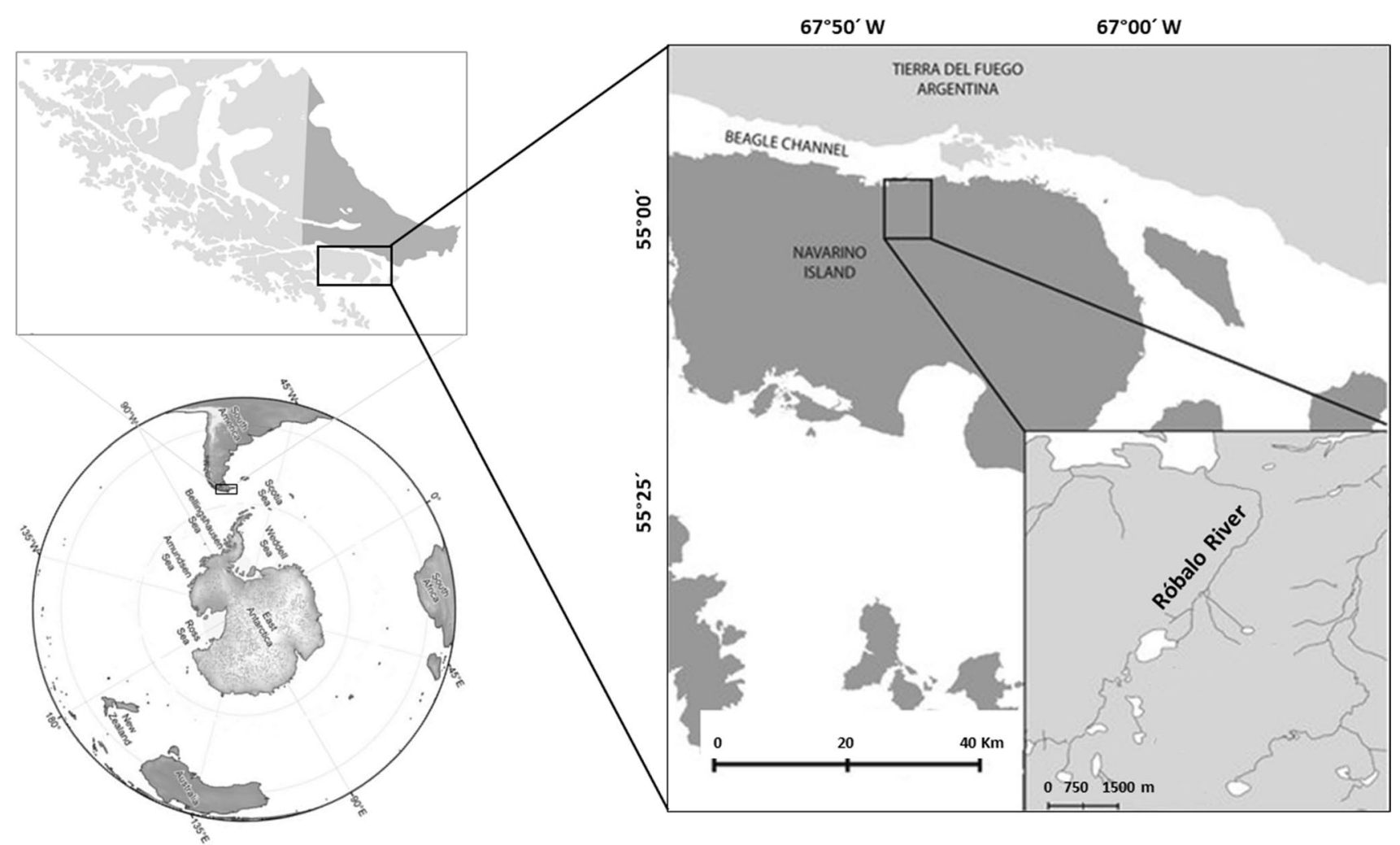

Fig. 1 Location of study area in Róbalo River on Navarino Island (Chile) in southern South America's sub-Antarctic region. This map was made using partial modifications of published cartographies from Antarctica (Downey et al. 2012) and Navarino Island (Rendoll Cárcamo et al. 2019)

taken for each sample type. Basal resources were collected using a core sampler $\left(0.07 \mathrm{~m}^{2}\right)$ and included (a) coarse benthic organic matter $(\mathrm{CBOM}>1 \mathrm{~mm})$, (b) very fine benthic organic matter $(0.7 \mu \mathrm{m}<\mathrm{VFBOM}<250 \mu \mathrm{m})$, and (c) biofilm. CBOM was obtained with a sieve, and VFBOM on pre-ashed filters $(0.7 \mu \mathrm{m}$, Whatman $\mathrm{GF} / \mathrm{F})$. Biofilm was collected using a stiff brush and core sampler on three to five rocks in the FS site for each replicate; rocky substrates were not available in BP. The slurry was removed and pipetted through pre-ashed Whatman GF/F filters. Dominant benthic macroinvertebrate consumers were determined for each functional feeding group (FFG): collector-gatherer (Amphipoda Hyalella spp.), collector-filterer (Diptera Gigantodax spp.), scraper (Ephemeroptera Meridialaris spp.), and predator (Trichoptera Rheochorema magallanicum) (Anderson and Rosemond 2007, 2010). Samples consisted of 10-15 g (wet weight, WW) of basal resources and $100 \mathrm{mg} \mathrm{WW}$ of macroinvertebrate tissue. After collection in the field, macroinvertebrates had their guts removed in the laboratory under a dissecting scope. The five replicates of each category were stored in aluminum foil or cryogenic vials. At the field site, samples were kept in liquid nitrogen; transported on dry ice and stored at $-80{ }^{\circ} \mathrm{C}$ until FA analysis within several months of sampling. Quantification of total lipid and individual FA (reported as mass fractions $=\mu \mathrm{g}$ FA per mg dry weight tissue extracted) was conducted at the National Water Research Institute (Environment Canada), using standard lipid extraction methods followed by gas chromatography (GC) analysis (McMeans et al. 2012).

All freeze-dried samples were weighed prior to FA analysis. Fatty acid methyl esters (FAME) were obtained in a three-step process: extraction, derivatization, and quantification on a gas chromatograph. Samples were extracted 3 times by grinding freeze-dried tissues in (2:1 v/v) chloroform:methanol (Folch et al. 1957), followed by centrifugation at 3300 r.p.m. to remove non-lipid material. Extracted lipids were brought to a final volume of $2 \mathrm{~mL}$. Duplicate $200 \mu \mathrm{L}$ aliquots were dispensed into pre-weighed tin cups, which were dried and reweighed on a Sartorius (Model ME5) microbalance with $\pm 1 \mu \mathrm{g}$ precision to provide a quantitative measure of total lipid content. Total lipid and FA content were reported as mass fraction $(\mu \mathrm{g})$ related to dry weight (DW) tissue or sample extracted. The remaining extract was then transferred into a Shimadzu vial (Sigma 27319U) and evaporated to dryness, using nitrogen gas and stored at $-80{ }^{\circ} \mathrm{C}$ until derivatization. For FAME formation, aliquots of the lipid extract were evaporated to near dryness under nitrogen in a pre-cleaned vial. Sulphuric acid in methanol (1:100 mixture used as a methylation reagent) and toluene were added to the vials, the headspace was 
flushed with nitrogen, the vial was vortexed and then incubated $(12 \mathrm{~h})$ at $50{ }^{\circ} \mathrm{C}$ in a water bath. After the samples were cooled, potassium hydrogen carbonate, isohexane:diethyl ether $(1: 1 \mathrm{v} / \mathrm{v})$, and butylated hydroxy toluene $(0.01 \% \mathrm{w} / \mathrm{v})$ were added, and the vials were vortexed and centrifuged. The upper organic layer was transferred to another labeled centrifuge tube; isohexane:diethyl ether $(1: 1 \mathrm{v} / \mathrm{v})$ was added to the original tube, which was then shaken, vortexed, and centrifuged. All FAME containing layers were pooled and concentrated under nitrogen. FAME were separated using a Hewlett Packard 6890 GC with the following configuration: splitless injection; column $=$ Supelco $($ SP- 2560 column $)$
$100 \mathrm{~m} \times 0.25 \mathrm{~mm} \mathrm{ID} \times 0.20-\mu \mathrm{m}$-thick film; oven $=140{ }^{\circ} \mathrm{C}$ (hold for $5 \mathrm{~min}$ ) to $240{ }^{\circ} \mathrm{C}$ at $4{ }^{\circ} \mathrm{C} \mathrm{min}{ }^{-1}$, hold for $12 \mathrm{~min}$; carrier gas $=$ helium, $1.2 \mathrm{~mL} \mathrm{~min}^{-1}$; detector $=$ FID at $260{ }^{\circ} \mathrm{C}$; injector $=260{ }^{\circ} \mathrm{C}$; total run time $=\sim 42 \mathrm{~min}$ per sample.

\section{Data analysis}

Using the extant literature, we compiled an inventory of relevant lipids used as biomarkers (Table 1). Based on this inventory, algal contribution to different organic matter categories was assessed using the sum of the following

Table 1 Fatty acids used as indicators of algae, bacteria, diatoms and fungi, as well as quality and origin (autochthonous vs allochthonous)

\begin{tabular}{|c|c|}
\hline Biomarker & Cite \\
\hline \multicolumn{2}{|l|}{ Bacteria } \\
\hline 15:0 & Kharlamenko et al. (1995), Najdek et al. (2002), Maazouzi et al. (2007), Torres-Ruiz et al. $(2007,2010)$ \\
\hline $15: 1$ & Kharlamenko et al. (1995), Maazouzi et al. (2007), Torres-Ruiz et al. (2007, 2010) \\
\hline 17:0 & Kharlamenko et al. (1995), Maazouzi et al. (2007), Torres-Ruiz et al. $(2007,2010)$ \\
\hline $17: 1$ & Kharlamenko et al. (1995), Maazouzi et al. (2007), Torres-Ruiz et al. $(2007,2010)$ \\
\hline 16:0 & Torres-Ruiz et al. (2007, 2010), Volkman et al. (2008) \\
\hline 18:0 & Napolitano (1999), Torres-Ruiz et al. (2007, 2010), Volkman et al. (2008) \\
\hline \multicolumn{2}{|l|}{ Diatoms } \\
\hline $16: 1 \mathrm{n}-7$ & $\begin{array}{l}\text { Napolitano (1994, 1997, 1999), Torres-Ruiz et al. (2007), Maazouzi et al. (2007), Volkmann et al. (2008), } \\
\text { Taipale et al. (2013) }\end{array}$ \\
\hline $20: 5 n-3$ & Napolitano (1994, 1997, 1999), Torres-Ruiz et al. (2007) \\
\hline \multicolumn{2}{|l|}{ Algae (not diatoms) } \\
\hline $18: 2 n-6$ & Torres-Ruiz et al. (2007), Napolitano (1994, 1999), Napolitano et al. (1997) \\
\hline $18: 3 n-3$ & Taipale et al. (2013), Volkmann et al. (2008), Gladyshev et al. (2013), Twining et al. (2016) \\
\hline $20: 3 n-3$ & Torres-Ruiz et al. (2007), Napolitano $(1994,1999)$ \\
\hline $22: 5 n-3$ & $\begin{array}{l}\text { Torres-Ruiz et al. (2007), Napolitano (1994, 1999), Dunstan et al. (1994), Budge and Parrish (1998), } \\
\text { Dalsgaard et al. (2003) }\end{array}$ \\
\hline $22: 6 n-3$ & Torres-Ruiz et al. (2007), Napolitano $(1994,1999)$ \\
\hline \multicolumn{2}{|l|}{ Algae/bryophytes } \\
\hline $20: 4 n-6$ & Torres-Ruiz et al. (2007) \\
\hline \multicolumn{2}{|l|}{ Fungi } \\
\hline $18: 1 \mathrm{n}-9$ & Torres-Ruiz et al. $(2007,2010)$ \\
\hline \multicolumn{2}{|l|}{ Quality (PUFA proportion) } \\
\hline $18: x n-3$ & Goedkoop et al. (1998) \\
\hline 18:xn-6 & Goedkoop et al. (1998) \\
\hline \multicolumn{2}{|l|}{ Autochthonous/allochthonous origin } \\
\hline n-3:n-6 & Torres-Ruiz et al. (2007), Taipale et al. (2014) \\
\hline \multicolumn{2}{|l|}{ Autochthonous origin } \\
\hline $20: 5 n-3(E P A)+22: 6 n 3(D H A)$ & Hixson et al. (2015) \\
\hline \multicolumn{2}{|l|}{ Allochthonous origin } \\
\hline 20:0 & Napolitano (1999), Boon and Duineveld (1996), Kawamura et al. (1987), Meyers et al. (1984) \\
\hline 21:0 & Napolitano (1999), Boon and Duineveld (1996), Kawamura et al. (1987), Meyers et al. (1984) \\
\hline 22:0 & Napolitano (1999), Boon and Duineveld (1996), Kawamura et al. (1987), Meyers et al. (1984) \\
\hline 23:0 & Napolitano (1999), Boon and Duineveld (1996), Kawamura et al. (1987), Meyers et al. (1984) \\
\hline 24:0 & Napolitano (1999), Boon and Duineveld (1996), Kawamura et al. (1987), Meyers et al. (1984) \\
\hline
\end{tabular}

The symbol " $x$ " in 18:xn-3 and 18:xn-6 refers to variable level of unsaturation 
individual FA: 16:1n-7, 18:3n-3, 18:2n-6, 20:3n-3, 20:5n$3,22: 5 n-3,22: 6 n-3$; while bacterial and fungal contribution was marked using odd number carbon chains FA and 18:1n-9, respectively. To evaluate the autochthonous and allochthonous FA origin, we used the relationship between omega-3 and omega-6 fatty acids (Torres-Ruiz et al. 2007; Taipale et al. 2014). Polyunsaturated FA (PUFA) contribution was used to measure resource and consumer FA quality (Goedkoop et al. 1998).

To detect differences in FA due to beaver activity, we used a $t$ test or Wilcoxon-Mann Whitney test (JMP 9.0 SAS) to compare the mean relative contribution $\left(\mathrm{FA}_{x} /\right.$ total FA) or ratio $\left(\mathrm{FA}_{x} / \mathrm{FA}_{y}\right.$ ) of biomarkers in basal resources (biofilm, VFBOM, CBOM) in BP and FS sites. To compare the complete profile of FS and BP sites under the hypothesis of no difference among groups of bacterial, fungi and algal FA contribution, we used an analysis of similarity (ANOSIM) with PRIMER v6.1.5 (Clarke and Gorley 2006). ANOSIM is a nonparametric procedure analogous to analysis of variance that tests differences in distance in the ordination matrix of FA contributions against random groups (a detailed procedure is provided by Clarke 1993). A total of 9999 random permutations were conducted to estimate the significance of the R test statistic associated with ANOSIM, following Clarke (1993).

Hyalella spp. was chosen for the consumer comparison between habitat types because it was the only abundant benthic macroinvertebrate in both sites, constituting more than $50 \%$ of biomass in both BP and FS habitat types (Anderson and Rosemond 2007). We then evaluated the FA profiles between four taxa (one from each major FFG; the collectorfilterer Gigantodax spp., the scraper Meridialaris spp., the collector-gatherer Hyalella spp., and the predator Rheochorema magallanicum) within the FS habitat to determine differences in trophic dynamics of natural sub-Antarctic streams, evaluating again the mean relative contribution and ratio of the FA biomarkers for each FFGs with a one-way ANOVA with a post hoc Tukey test (JMP 9.0 SAS; Infostat; Di Rienzo et al. 2016).

\section{Results}

The FA profile from all samples taken in the BP and FS sites is shown in Table 2. From these data, we were able to obtain information regarding the origin, composition and quality of basal resources available and consumed by benthic macroinvertebrates.

\section{Carbon source}

We detected a trend of higher mass fraction of allochthonous, long-chain saturated fatty acids (SFA, see Table 1) in
FS compared to BP samples, which was statistically significant for CBOM $(t=-9.87$, d.f. $=8, p<0.0001)$ and Hyalella spp. $(t=-6.96$, d.f. $=8, p=0.0001)$ (Fig. 2a; Table 2). The proportion of autochthonous versus allochthonous FA (see Table 2) indicated there was little difference between BP and FS samples, with the exception of consumers (amphipods), which had a significantly higher proportion of autochthonous FA in BP reaches $(t=6.11$, d.f. $=8, p=0.0003)$. Moreover, autochthonous contribution, measured as the sum of 20:5n-3 (EPA) and 22:6n-3 (DHA), was significantly higher in BP than FS for CBOM and Hyalella spp. ( $W=40, p=0.008$; $W=38, p=0.03$, respectively; Table 2).

Macroinvertebrate consumers from all sampled functional feeding groups (collector-gatherer Hyalella spp., collectorfilterer Gigantodax spp., scraper Meridialaris spp. and predator $R$. magellanicum) were abundant in the FS site. Meridialaris spp. and $R$. magellanicum showed no allochthonous contribution and could not be assessed, since the proportion could not be made due to 0 values of allochthonous biomarkers. Regarding consumer basal resource dependence, the collector-filterer Gigantodax spp. had a greater proportion of autochthonous FA (i.e. > autochthonous/allochthonous ratio), compared to the collector-gatherer Hyalella spp. $\left(F_{3,16}=5437, p<0.0001\right)$ (Table 2).

\section{Composition of basal resources}

The similarity analysis for FA from basal resources and from a collector-gatherer in BP and FS showed significant differences (Global $R=0.719, p=0.001$ ), when considering FA contributions among CBOM, VFOM, and Hyalella spp. Overall, the relative contribution of algal and diatom FA was higher in BP, compared to FS, and this effect was significant for $\operatorname{CBOM}(t=8.1$, d.f. $=8, p<0.0001)$ (Fig. 3a). Among FS basal resources, biofilm showed the highest concentration of algal and diatom FA, following by VFBOM and CBOM (Fig. 3a). Bacterial FA biomarkers were higher in BP than FS for CBOM $(t=5.94$, d.f. $=4, p=0.004)$ (Fig. 3b), while fungi FA biomarkers only increased significantly in FS for $\operatorname{VFBOM}(t=-3.16$, d.f. $=7, p=0.02$; Fig. 3c). Biofilm displayed more fungi FA biomarkers than the other two basal resources, as it also did with algae and diatom FA biomarkers (Fig. 3c).

\section{Comparison of consumers}

The amphipod Hyalella spp. showed a higher mass fraction of allochthonous FA biomarkers in BP compared to FS samples ( $t=-6.96$, d.f. $=8, p=0.0001$ ) (Fig. 2a). Algal and bacterial FA biomarkers were higher in BP than FS for the amphipod Hyalella spp. $(t=8.1$, d.f. $=8, p<0.0001 ; t=5.48$, d.f. $=8, p=0.0006$; respectively) (Fig. 4). Moreover, in BP, Hyalella spp. showed a higher proportion of algal and 
Table 2 Mean mass fraction in $\mu$ g related to the dried mass $( \pm \mathrm{SE})$ of fatty acids in benthic basal resources and macroinvertebrates from sites in a beaver pond and a natural forested stream

\begin{tabular}{|c|c|c|c|c|c|c|c|c|c|}
\hline \multirow[t]{2}{*}{ Fatty acid } & \multicolumn{3}{|c|}{ Beaver pond (BP) stream } & \multicolumn{6}{|c|}{ Natural forest (FS) stream } \\
\hline & VFBOM & CBOM & Hyalella spp. & VFBOM & $\mathrm{CBOM}$ & Hyalella spp. & $\begin{array}{l}\text { Gigantodax } \\
\text { spp. }\end{array}$ & $\begin{array}{l}\text { Meridialaris } \\
\text { spp. }\end{array}$ & $\begin{array}{l}\text { Rheochorema } \\
\text { magallanicum }\end{array}$ \\
\hline 14:0 & $0.01(0.01)$ & $0.03(0.01)$ & $0.17(0.01)$ & $0.01(0.00)$ & $0.05(0.01)$ & $0.11(0.01)$ & $0.20(0.01)$ & $0.24(0.03)$ & $0.21(0.02)$ \\
\hline $15: 0$ & & & $0.12(0.01)$ & $0.01(0.00)$ & $0.12(0.01)$ & $0.15(0.01)$ & $0.11(0.01)$ & $0.12(0.01)$ & $0.10(0.01)$ \\
\hline $16: 0$ & $0.04(0.00)$ & $0.16(0.02)$ & $4.47(0.08)$ & $0.05(0.01)$ & $0.20(0.01)$ & $4.03(0.11)$ & $7.85(0.09)$ & $7.83(0.25)$ & $9.84(0.52)$ \\
\hline $17: 0$ & & & $0.27(0.01)$ & & $0.04(0.01)$ & $0.35(0.01)$ & $0.54(0.02)$ & $1.14(0.03)$ & $0.84(0.11)$ \\
\hline 18:0 & $0.01(0.00)$ & $0.06(0.01)$ & $1.11(0.03)$ & $0.02(0.00)$ & $0.09(0.01)$ & $1.10(0.02)$ & $2.03(0.02)$ & $4.11(0.09)$ & $3.91(0.25)$ \\
\hline 20:0 & $0.01(0.00)$ & $0.10(0.02)$ & $0.05(0.00)$ & $0.03(0.01)$ & $0.46(0.07)$ & $0.07(0.01)$ & $0.21(0.01)$ & $0.27(0.01)$ & $0.26(0.03)$ \\
\hline $21: 0$ & & $0.02(0.01)$ & & $0.03(0.01)$ & & $0.02(0.00)$ & $0.05(0.01)$ & $0.02(0.01)$ & $0.05(0.01)$ \\
\hline $22: 0$ & $0.02(0.00)$ & $0.01(0.00)$ & $0.07(0.01)$ & & $0.66(0.06)$ & $0.09(0.01)$ & & $0.27(0.02)$ & $0.25(0.04)$ \\
\hline $24: 0$ & & $0.01(0.00)$ & & & & & & & \\
\hline Total SFA & $0.10(0.04)$ & $0.39(0.09)$ & $6.26(0.15)$ & $0.15(0.03)$ & $1.62(0.18)$ & $5.92(0.18)$ & $10.99(0.17)$ & $14.00(0.45)$ & $15.46(0.99)$ \\
\hline$\%$ SFA/FA & 41.7 (16.7) & $44.8(10.3)$ & $18.1(0.4)$ & $55.6(11.1)$ & $69.5(7.7)$ & $18.0(0.5)$ & $24.0(0.4)$ & $24.1(0.8)$ & $25.5(1.6)$ \\
\hline $14: 1 n-5$ & & & & & & & $0.02(0.02)$ & & \\
\hline $15: 1$ & & & & & & & & & \\
\hline $16: 1 n-7$ & $0.06(0.03)$ & $0.11(0.02)$ & $0.92(0.03)$ & $0.03(0.01)$ & $0.05(0.01)$ & $0.56(0.04)$ & $4.39(0.08)$ & $4.01(0.17)$ & $3.68(0.37)$ \\
\hline $17: 1$ & & & & & $0.01(0.00)$ & & & $0.04(0.01)$ & \\
\hline $18: 1 n-9$ & & $0.01(0.00)$ & $0.04(0.01)$ & & $0.02(0.01)$ & $0.04(0.01)$ & $0.06(0.01)$ & $0.04(0.01)$ & $0.07(0.01)$ \\
\hline $18: 1 n-9$ & $0.01(0.00)$ & $0.07(0.02)$ & $8.26(0.08)$ & $0.02(0.00)$ & $0.14(0.01)$ & $8.16(0.40)$ & $8.23(0.08)$ & $6.19(0.16)$ & $9.66(0.52)$ \\
\hline $20: 1 n-9$ & & & $0.68(0.01)$ & & $0.02(0.01)$ & $0.56(0.01)$ & $0.08(0.01)$ & $0.24(0.01)$ & $0.17(0.02)$ \\
\hline $22: 1 n-9$ & & & $0.04(0.01)$ & & & $0.03(0.01)$ & & & $0.01(0.00)$ \\
\hline 24:1n-9 & & & $0.09(0.01)$ & & $0.01(0.01)$ & $0.08(0.01)$ & & & \\
\hline Total MUFA & $0.07(0.04)$ & $0.19(0.05)$ & $10.03(0.15)$ & $0.05(0.02)$ & $0.25(0.06)$ & $9.43(0.48)$ & $12.78(0.20)$ & $10.52(0.37)$ & $13.59(0.93)$ \\
\hline$\%$ MUFA/FA & $29.2(16.7)$ & $21.8(5.7)$ & $29.0(0.4)$ & $18.5(7.4)$ & 10.7 (2.6) & $28.6(1.5)$ & $27.9(0.4)$ & $18.1(0.6)$ & $22.1(1.5)$ \\
\hline $18: 2 n-6$ & $0.01(0.00)$ & $0.09(0.03)$ & $3.11(0.10)$ & $0.02(0.00)$ & $0.17(0.01)$ & $3.41(0.16)$ & $4.72(0.04)$ & $3.65(0.20)$ & $3.72(0.15)$ \\
\hline $18: 3 n-6$ & & $0.01(0.01)$ & $0.14(0.01)$ & & $0.01(0.00)$ & $0.10(0.01)$ & $0.18(0.01)$ & $0.18(0.01)$ & $0.16(0.02)$ \\
\hline $18: 3 n-3$ & $0.01(0.00)$ & $0.07(0.04)$ & $1.63(0.07)$ & $0.01(0.00)$ & $0.15(0.01)$ & $1.66(0.14)$ & $7.52(0.07)$ & $14.07(0.40)$ & $13.36(1.83)$ \\
\hline $20: 2$ & & $0.01(0.00)$ & $0.55(0.02)$ & & & $0.60(0.02)$ & $0.03(0.01)$ & $0.07(0.01)$ & $0.06(0.01)$ \\
\hline $20: 3 n-6$ & & & $0.09(0.01)$ & & & $0.09(0.01)$ & $0.03(0.01)$ & $0.06(0.01)$ & $0.03(0.01)$ \\
\hline $20: 3 n-3$ & & & $0.26(0.02)$ & & $0.02(0.00)$ & $0.22(0.01)$ & $0.03(0.01)$ & $0.28(0.01)$ & $0.11(0.02)$ \\
\hline $20: 4 n-6$ & $0.02(0.00)$ & $0.06(0.01)$ & $2.78(0.05)$ & $0.02(0.01)$ & $0.09(0.01)$ & $3.43(0.11)$ & $1.02(0.02)$ & $1.19(0.04)$ & $1.62(0.09)$ \\
\hline $22: 2$ & & & $0.01(0.01)$ & & & $0.01(0.00)$ & & & \\
\hline $20: 5 n-3$ & $0.03(0.01)$ & $0.05(0.01)$ & $7.42(0.20)$ & $0.01(0.00)$ & $0.02(0.01)$ & $6.25(0.19)$ & $8.31(0.10)$ & $13.99(0.23)$ & $13.12(1.04)$ \\
\hline $22: 5 n-3$ & & & $0.89(0.02)$ & & & $0.88(0.03)$ & & & $0.09(0.01)$ \\
\hline $22: 6 n-3$ & & & $1.43(0.11)$ & $0.01(0.00)$ & & $0.95(0.07)$ & $0.18(0.01)$ & $0.01(0.00)$ & $0.04(0.03)$ \\
\hline Total PUFA & $0.07(0.04)$ & $0.29(0.11)$ & $18.31(0.62)$ & $0.07(0.02)$ & $0.46(0.06)$ & $17.62(0.76)$ & $22.02(0.28)$ & $33.49(0.92)$ & $32.31(3.21)$ \\
\hline$\%$ PUFA/FA & $29.2(16.7)$ & $33.3(12.6)$ & $52.9(1.8)$ & $25.9(7.4)$ & 19.7 (2.6) & $53.4(2.3)$ & $48.1(0.6)$ & $57.7(1.6)$ & $52.7(5.2)$ \\
\hline
\end{tabular}

FA contribution units are $\mu \mathrm{g}$ per $\mathrm{mg}$ dried weight

SFA saturated fatty acids, MUFA monounsaturated fatty acids, PUFA polyunsaturated fatty acids

fungal FA biomarkers than VFBOM and CBOM biomarkers (Table 2).

Similarly, the mass fraction of algal FA was significantly greater in the scraper Meridialaris spp., followed by the collector-filterer Gigantodax spp. and predator R. magallanicum, and lastly the collector-gatherer Hyalella spp. $\left(F_{3,16}=75.57, p<0.0001\right)$ (Fig. 4). On the other hand, bacterial fractions were lower in amphipods than the other FFGs
$\left(F_{3,16}=83.04, p<0.0001\right)$. Finally, the relative contribution of fungal FA was significantly lower in the scraper Meridialaris spp. than the other FFGs $\left(F_{3,16}=10.64, p=0.0004\right)$ (Fig. 4).

Fatty acids composition between Hyalella spp. from FS and BP differed in the contribution of each FA group, basal resource origin and quantity (26 and 24 FA contributed in FS and BP, respectively; Table 2). Moreover, this PUFA was 

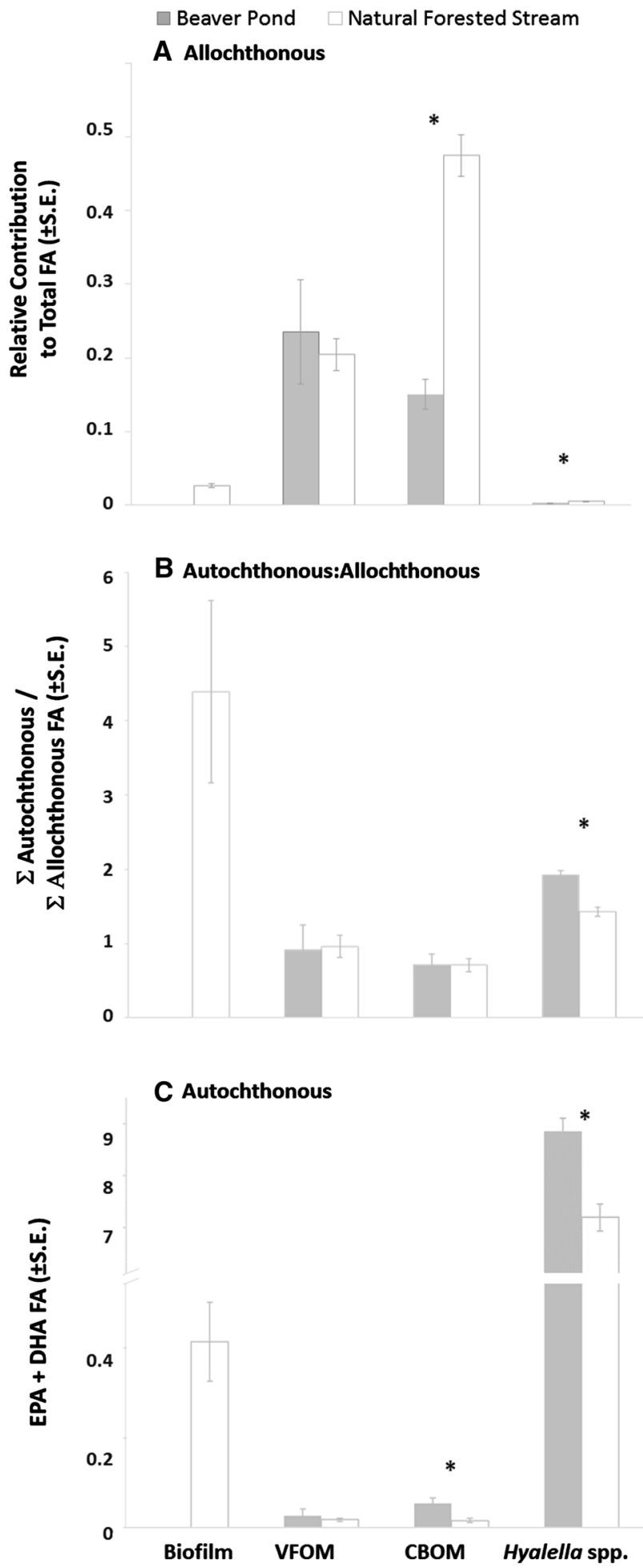

Fig. 2 Mean relative contribution $( \pm$ SE) of fatty acid (FA) indicators to total FA from samples of biofilm, very fine benthic organic matter (VFBOM), and coarse benthic organic matter (CBOM) were compared between beaver ponds (BP: gray shading) and natural forested streams (FS: no shading) for biomarkers of a allochthonous, $\mathbf{b}$ autochthonous:allochthonous, and $\mathbf{c}$ autochthonous measured as the sum of DHA and EPA. Asterisk (*) indicates statistically significant differences only detected in small amounts in Hyalella spp. Comparing all consumers in FS, it is remarkable that Gigantodax spp. had no 22:0, and the contribution of the 14:0 in these organisms differed from the other consumers (Table 2).

\section{Relative contribution of PUFA}

FA quality (mean relative contribution of polyunsaturated fatty acids $=$ PUFA) was observed to be significantly higher in CBOM from FS than in CBOM in BP samples $(t=4.48$, d.f. $=4, p=0.01$; mean $\pm \mathrm{SD}=0.46 \pm 0.06$ and $0.29 \pm 0.11$, respectively) and tended to be higher in $\mathrm{Hya}$ lella spp. $(t=1.86$, d.f. $=8, p=0.09)$ (Fig. 5; Table 2). On the other hand, VFBOM PUFA in FS showed more than a $10 \%$ contribution of DHA, which was less than $2 \%$ in BP-VBOM samples; similarly, 20:3n-3 was only detected in BP CBOM (Table 2). The collector-gatherer Hyalella spp. and the collector-filterer Gigantodax spp. showed a decreasing pattern in the mass fraction of PUFA $>$ monounsaturated fatty acids (MUFA) $>$ SFA, meaning that better quality FA (PUFA, which cannot be synthesized by most animals) was greater than modified forms of FA (MUFA and SFA), while R. magellanicum and Meridialaris spp. showed PUFA $>$ SFA $>$ MUFA (Table 2). The principle macroinvertebrate SFA were 16:0, 18:0, 17:0, while common MUFA were 18:1n-9, 16:1n-7, and 20:1n-9. Major PUFA represented in the samples included 20:5n-3, 18:3n-3, 18:2n-6, and 20:4n-6. In both sites, CBOM and VFBOM FA composition displayed the following pattern of abundance: SFA (mostly 16:0 and 18:0) > PUFA > MUFA (Table 2).

\section{Discussion}

Beaver effects on benthic food webs are relevant at the landscape-scale in Tierra del Fuego's sub-Antarctic streams because, on average, they increased the retention of organic matter in watersheds by $72 \%$ (Anderson et al. 2014), and they also increase the decomposition rate of $N$. pumilio leaves (Ulloa et al. 2012). By integrating the present study's FA results to previous knowledge of sub-Antarctic limnology, we now can add several new insights and re-affirm other aspects of aquatic ecology in southern Patagonia. This study supports previous assertions that Tierra del Fuego's subAntarctic stream consumers are underpinned by a variety of basal resources (Anderson and Rosemond 2010). However, we here we also identify previously undocumented consumption from algal, fungal and bacterial sources. The previous TBP study by Anderson and Rosemond (2010) also showed that amorphous detritus was a dominant energy flow pathway in both FS and BP. Here, we report that benthic consumers all had relatively high contributions of algal and diatom FA to their overall lipid profile ( $>40 \%)$. This finding 
Fig. 3 Mean relative contribution $( \pm \mathrm{SE})$ of fatty acid (FA) indicators to total FA from samples of biofilm, very fine benthic organic matter (VFBOM), and coarse benthic organic matter (CBOM) were compared between beaver ponds (BP: gray shading) and natural forested streams (FS: no shading) for biomarkers (see Table 1) of a algae and diatoms, $\mathbf{b}$ bacteria, and $\mathbf{c}$ fungi. Asterisk (*) indicates statistical significant differences. Table 1 indicates FA selected for each category. Table 2 indicates the contribution to FAs for each resource or consumer

indicates that even though the contribution of autochthonous-derived FA is low in the basal resources sampled in $\mathrm{BP}$, they are important for these consumers. Likewise, it helps interpret stable isotope results, which had unexplained sources.

Overall, we obtained evidence to partially support the hypothesis that beaver invasion increases the contribution of autochthonous basal resources, which are, furthermore, of higher quality. For example, the amount of PUFA (an indicator of quality due to its physiological importance for consumers; Ahlgren et al. 1997; Brett and Müller-Navarra 1997) in CBOM was greater in BP sites than FS, which also translated to greater amounts of PUFA in the consumer Hyalella spp. from BP. Plus, the relative contribution of terrestrially derived long-chain SFA was significantly greater in FS sites than BP sites. BP sites might have greater primary production or at least this production is more available to benthic consumers. Furthermore, even though the autochthonous/ allochthonous FA ratio is very low in these resources, it is much higher in the consumer, indicating either an unidentified autochthonous dietary source or the selective retention of these essential FA (e.g., due to FA differences in retentive metabolism in organisms, Kainz et al. 2004). We note that previous gut analyses did not reveal filamentous algae or cyanobacteria as other potential aquatic primary production basal resources, but diatoms were observed to increase in BP as a proportion of gut contents (Anderson and Rosemond 2010). Thus, FA analysis integrates information of autochthonous contribution that was not possible to reveal from gut contents analysis. Moreover, considering the metrics proposed by Torres-Ruiz et al. (2007), Taipale et al. (2014) and Hixson et al. (2015), we showed a shift in the carbon origin in BP by evaluating the possible sources and Hyalella spp. as a consumer. We can also recommend the use of this amphipod as a good sentinel species for these systems. Hyalela spp. broadly integrated the underlying ecosystem changes fueled by the beaver's ecosystem engineering activities.

Until now it was not possible to elucidate the constituent microbial components of basal resources. For example, stable isotopes did not clarify the origin of basal resources, since measured autochthonous and allochthonous basal resource signatures were not distinguishable, and therefore, mixing models were not possible to clarify the relative contribution of these organic matter sources (Anderson $\square$ Beaver Pond $\square$ Natural Forested Stream

\section{A Algae+ Diatoms}

0.5

0.4

0.3

0.2

0.1

0.0

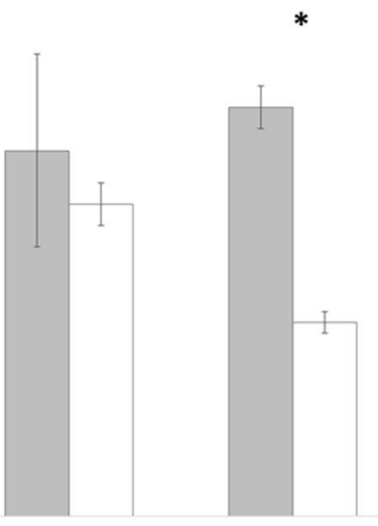

0.0

\section{B Bacteria}

0.5

0.4

0.3

0.2

0.1

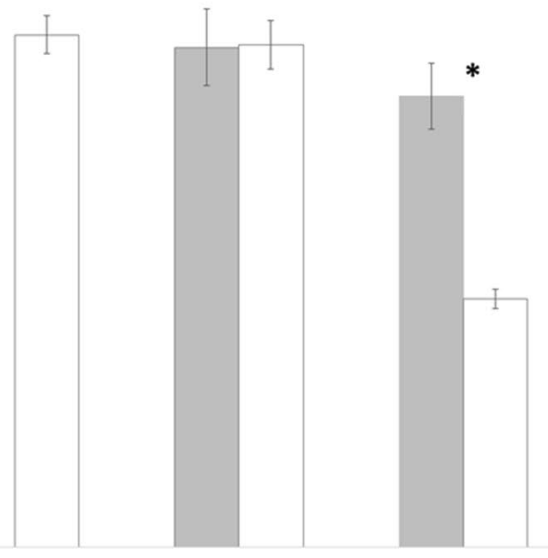

0.5

C Fungi

0.4

0.3

0.2

0.1

0.0 


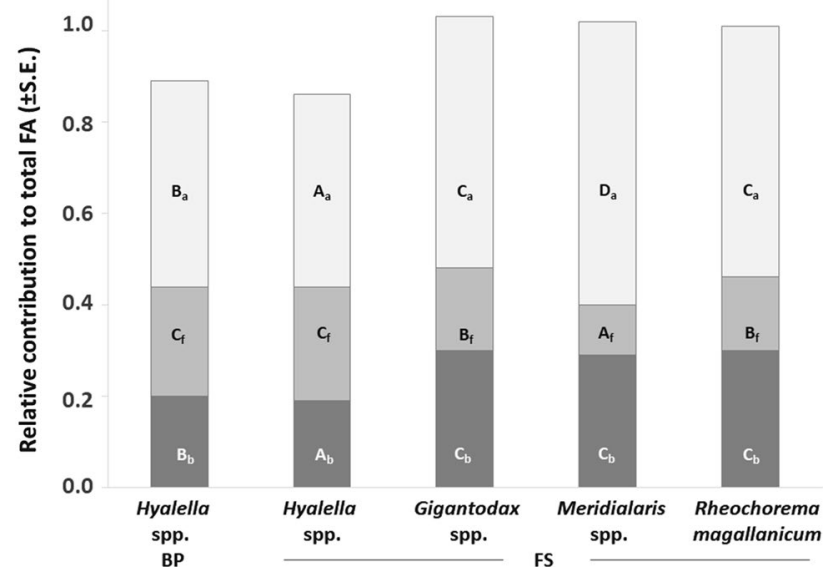

Fig. 4 Mean contribution ( \pm SE) of fatty acid (FA) biomarkers for algae $\left({ }_{\mathrm{a}}\right)$, fungi $\left({ }_{\mathrm{f}}\right.$ ), and bacteria $\left({ }_{\mathrm{b}}\right)$ were compared among Hyalella spp. in BP and FS sites, and Gigantodax spp., Meridialaris spp. and Rheochorema magallanicum. in FS. The same letter indicates that there were no significant differences between the mean contribution of algae, bacteria or fungi among species. Different letters indicate significant contribution differences, but the direction of the effect is illustrated with $\mathrm{A}$ indicating a significantly lower value than $\mathrm{B}$, similarly for $\mathrm{B}$ and $\mathrm{C}$, and $\mathrm{C}$ and $\mathrm{D}$. Table 1 indicates FA selected for each category. Table 2 indicates the contribution of FA to each source or consumer

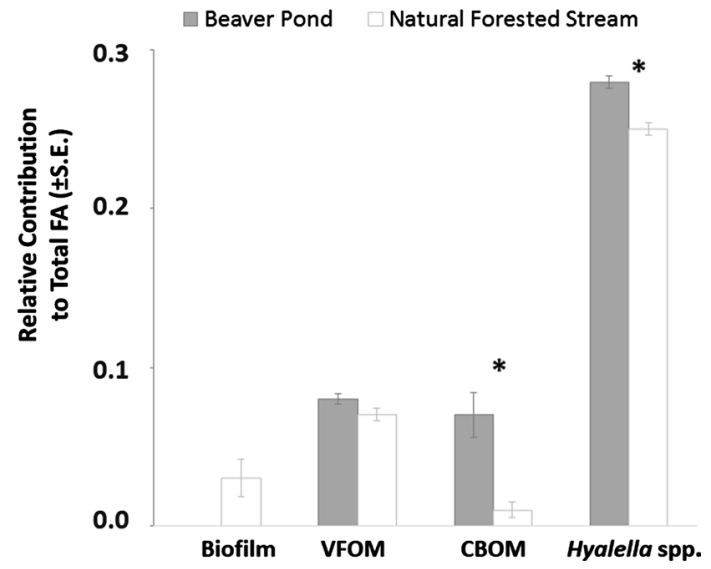

Fig. 5 Mean relative contribution $( \pm S E)$ of polyunsaturated fatty acid (PUFA) indicators to total FA from samples of biofilm, very fine benthic organic matter (VFBOM), coarse benthic organic matter $(\mathrm{CBOM})$ and the collector-gather macroinvertebrate consumer Hyalella spp. were compared between beaver ponds (BP: gray shading) and natural forested streams (FS: no shading) for biomarkers (see Table 1) of quality (contribution of PUFA to total FA). Asterisk (*) indicates statistically significant differences. Table 1 shows FA selected for each category. Table 2 illustrates the contribution to fatty acids to each resource or consumer

and Rosemond 2010). Here, we found that biofilm had FA indicative of both autotrophs and heterotrophs, specifically the relative contributions of algae and diatom FAs were approximately twice that of the fungal FA, which in turn were an order of magnitude higher than those from bacteria. This finding is also supported by the FA indicators in the scraper Meridialaris sp., which is very similar to those of biofilm (i.e. its most important food item). It is of note that all three basal resource types measured here had FA from both autotrophs and heterotrophs (with a higher contribution of autotrophs). In particular, fungi did not show up in the previous dietary studies, but is apparently a significant item in consumer diets and is found in all basal resources.

In conclusion, these findings support previous evidence that sub-Antarctic stream benthic food webs are based largely on allochthonous organic material. However, they also highlight the previously underappreciated role of autochthonous production in these systems. Further, our study provides initial evidence regarding the constituent parts of major basal resource categories. Thus, the effects of beaver invasion on sub-Antarctic streams not only increases secondary production by an order of magnitude and decreases benthic macroinvertebrate diversity (Anderson and Rosemond 2007), and it also affects the origin, composition and quality of organic matter in these streams.

Acknowledgements Christopher B. Anderson, Amy D. Rosemond and Aaron Fisk acknowledge NSF award DEB-0407875 that supported the sample analyses. Field work was financed by a U.S.-Chile Fulbright Scholarship and NSEP Boren Fellowship to Christopher B. Anderson and a CONICET postdoctoral fellowship financed Marina Tagliaferro. Michael T. Arts received support for this study from Environment Canada and Ryerson University (NSERC Discovery Grant \#04537-2014). Two anonymous reviewers provided recommendations that enhanced our paper.

\section{Compliance with ethical standards}

Conflict of interest The authors declare that they have no conflict of interest.

\section{References}

Ahlgren G, Goedkoop W, Markensten H et al (1997) Seasonal variations in food quality for pelagic and benthic invertebrates in Lake Erken - the role of fatty acids. Freshw Biol 38:555-570. https:// doi.org/10.1046/j.1365-2427.1997.00219.x

Anderson CB, Rosemond AD (2007) Ecosystem engineering by invasive exotic beavers reduces in-stream diversity and enhances ecosystem function in Cape Horn, Chile. Oecologia 154:141-153. https://doi.org/10.1007/s00442-007-0757-4

Anderson CB, Rosemond AD (2010) Beaver invasion alters terrestrial subsidies to subantarctic stream food webs. Hydrobiologia 652:349-361. https://doi.org/10.1007/s10750-010-0367-8

Anderson CB, Rozzi R, Torres-Mura JC et al (2006) Exotic vertebrate fauna in the remote and pristine sub-Antarctic Cape Horn Archipelago, Chile. Biodivers Conserv 15:3295-3313. https://doi. org/10.1007/s10531-005-0605-y

Anderson CB, Martínez Pastur G, Lencinas MV et al (2009) Do introduced North American beavers Castor canadensis engineer differently in southern South America? An overview with implications 
for restoration. Mamm Rev 39:33-52. https://doi.org/10.111 1/j.1365-2907.2008.00136.x

Anderson CB, Lencinas MV, Wallem PK et al (2014) Engineering by an invasive species alters landscape-level ecosystem function, but does not affect biodiversity in freshwater systems. Divers Distrib 20:214-222. https://doi.org/10.1111/ddi.12147

Arts MT, Wainman BC (1999) Lipids in freshwater ecosystems. Springer, New York

Arts MT, Brett MT, Kainz M (2009) Lipids in aquatic ecosystems. Springer, New York

Ballari SA, Cuevas MF, Cirignoli S, Valenzuela AEJ (2015) Invasive wild boar in Argentina: using protected areas as a research platform to determine distribution, impacts and management. Biol Invasions 17:1595-1602. https://doi.org/10.1007/s1053 0-014-0818-7

Benke AC (2018) River food webs: an integrative approach to bottomup flow webs, top-down impact webs, and trophic position. Ecology 99:1370-1381. https://doi.org/10.1002/ecy.02228

Benke AC, Wallace JB (1980) Trophic basis of production among netspinning caddisflies in a Southern Appalachian stream. Ecology 61:108-118

Bierwagen SL, Pethybridge H, Heupel MR et al (2019) Trophic niches determined from fatty acid profiles of sympatric coral reef mesopredators. Mar Ecol Prog Ser 632:159-174. https://doi. org/10.3354/meps 13150

Boon A, Duineveld GCA (1996) Phytopigments and fatty acids as molecular markers for the quality of near-bottom particulate organic matter in the North Sea. J Sea Res 35:279-291. https:// doi.org/10.1016/s0077-7579(96)90084-8

Brett MT, Müller-Navarra DC (1997) The role of highly unsaturated fatty acids in aquatic food web processes. Freshw Biol 38:483-499

Budge SM, Parrish CC (1998) Lipid biogeochemistry of plankton, settling matter and sediments in Trinity Bay, Newfoundland. II. Fatty acids. Org Geochem 29:1547-1559. https://doi.org/10.1016/ S0146-6380(98)00177-6

Clarke KR (1993) Non-parametric multivariate analyses of changes in community structure. Aust J Ecol 18:117-143. https://doi. org/10.1111/j.1442-9993.1993.tb00438.x

Clarke KR, Gorley RN (2006) PRIMER v6: user manual/tutorial (Plymouth routines in multivariate ecological research). PRIMERE, Plymouth

Cross WF, Wallace JB, Rosemond AD (2007) Nutrient enrichment reduces constraints on material flows in a detritus-based food web. Ecology 88:2563-2575. https://doi.org/10.1890/06-1348.1

Dalsgaard J, St. John M, Kattner G et al (2003) Fatty acid trophic markers in pelagic marine environment. Adv Mar Biol 46:227-318

Di Rienzo JA, Casanoves F, Balzarini MG et al (2016) InfoStat versión 2016. Grupo InfoStat, FCA, Universidad Nacional de Córdoba, Córdoba

Downey RV, Griffiths HJ, Linse K, Janussen D (2012) Diversity and distribution patterns in high southern latitude sponges. PLoS ONE 7:e41672. https://doi.org/10.1371/journal.pone.0041672

Dunstan GA, Volkman JK, Barrett SM et al (1994) Essential polyunsaturated fatty acids from 14 species of diatom (Bacillariophyceae). Phytochemistry 35:155-161. https://doi.org/10.1016/S0031 -9422(00)90525-9

Folch J, Lees M, Stanley GHS (1957) A simple method for the isolation and purification of total lipides from animal tissues. J Biol Chem 226:497-509

Gladyshev MI, Sushchik NN, Makhutova ON (2013) Production of EPA and DHA in aquatic ecosystems and their transfer to the land. Prostaglandins Other Lipid Mediat 107:117-126. https:// doi.org/10.1016/j.prostaglandins.2013.03.002

Goedkoop W, Sonesten L, Markensten H, Ahlgren G (1998) Fatty acid biomarkers show dietary differences between dominant chironomid taxa in Lake Erken. Freshw Biol 40:135-143. https:// doi.org/10.1046/j.1365-2427.1998.00339.x

Guo F, Kainz MJ, Sheldon F, Bunn SE (2016) The importance of highquality algal food sources in stream food webs-current status and future perspectives. Freshw Biol 61:815-831. https://doi. org/10.1111/fwb.12755

Hixson SM, Sharma B, Kainz M et al (2015) Production, distribution, and abundance of long-chain omega- 3 between freshwater and terrestrial ecosystems. Environ Rev 23:414-424. https://doi. org/10.1139/er-2015-0029

Jardine TD, Woods R, Marshall J et al (2015) Reconciling the role of organic matter pathways in aquatic food webs by measuring multiple tracers in individuals. Ecology 96:3257-3269. https:// doi.org/10.1890/14-2153.1

Kainz M, Arts MT, Mazumder A (2004) Essential fatty acids in the planktonic food web and their ecological role for higher trophic levels. Limnol Oceanogr 49:1784-1793. https://doi.org/10.4319/ 10.2004.49.5.1784

Kawamura K, Ishiwatari R, Ogura K (1987) Early diagenesis of organic matter in the water column and sediments: microbial degradation and resynthesis of lipids in Lake Haruna. Org Geochem 11:251264. https://doi.org/10.1016/0146-6380(87)90036-2

Kharlamenko VI, Zhukova NV, Khotimchenko SV et al (1995) Fatty acids as markers of food sources in a shallow-water hydrothermal ecosystem (Kraternaya Bight, Yankich Island, Kurile Islands). Mar Ecol Prog Ser 120:231-242. https://doi.org/10.3354/meps1 20231

Kominoski JS, Rosemond AD (2012) Conservation from the bottom up: forecasting effects of global change on dynamics of organic matter and management needs for river networks. Freshw Sci 31:51-68. https://doi.org/10.1899/10-160.1

Larson JH, Richardson WB, Knights BC et al (2013) Fatty acid composition at the base of aquatic food webs is influenced by habitat type and watershed land use. PLoS ONE 8:e70666. https://doi. org/10.1371/journal.pone.0070666

Lau DCP, Leung KMY, Dudgeon D (2008) Experimental dietary manipulations for determining the relative importance of allochthonous and autochthonous food resources in tropical streams. Freshw Biol 53:139-147. https://doi.org/10.111 1/j.1365-2427.2007.01873.x

Maazouzi C, Masson G, Izquierdo MS, Pihan JC (2007) Fatty acid composition of the amphipod Dikerogammarus villosus: Feeding strategies and trophic links. Comp Biochem Physiol 147:868-875. https://doi.org/10.1016/j.cbpa.2007.02.010

McMeans BC, Arts MT, Rush SA, Fisk AT (2012) Seasonal patterns in fatty acids of Calanus hyperboreus (Copepoda, Calanoida) from Cumberland Sound, Baffin Island, Nunavut. Mar Biol 159:10951105. https://doi.org/10.1007/s00227-012-1889-6

Meyers PA, Leenheer MJ, Eaoie BJ, Maule SJ (1984) Organic geochemistry of suspended and settling particulate matter in Lake Michigan. Geochim Cosmochim Acta 48:443-452. https://doi. org/10.1016/0016-7037(84)90273-4

Mittermeier RA, Mittermeier CG, Brooks TM et al (2003) Wilderness and biodiversity conservation. Proc Natl Acad Sci USA 100:10309-10313. https://doi.org/10.1073/pnas.1732458100

Moorman MC, Eggleston DB, Anderson CB et al (2009) Implications of Beaver Castor canadensis and Trout Introductions on Native Fish in the Cape Horn Biosphere Reserve, Chile. Trans Am Fish Soc 138:306-313. https://doi.org/10.1577/T08-081.1

Najdek M (2002) Fatty acid and phytoplankton compositions of different types of mucilaginous aggregates in thenorthern Adriatic. $\mathrm{J}$ Plankton Res 24:429-441. https://doi.org/10.1093/plankt/24.5.429

Naiman RJ, Melillo JM, Hobbie JE (1986) Ecosystem alteration of boreal forest streams by beaver (Castor canadensis). Ecology 67:1254-1269. https://doi.org/10.1017/CBO9781107415324.004 
Napolitano GE (1994) The relationship of lipids with light and chlorophyll measurements in freshwater algae and periphyton. J Phycol 30:943-950

Napolitano GE (1999) Fatty acids as chemical and trophic markers in freshwater ecosystems. In: Arts M, Brett M, Kainz M (eds) Lipids in freshwater ecosystems. Springer, New York, pp 21-44

Napolitano GE, Pollero RJ, Gayoso AM et al (1997) Fatty acids as trophic markers of phytoplankton blooms in the Bahia Blanca estuary (Buenos Aires, Argentina) and in Trinity Bay (Newfoundland, Canada). Biochem Syst Ecol 25:739-755. https://doi. org/10.1016/S0305-1978(97)00053-7

Papier CM, Poulos HM, Kusch A (2019) Invasive species and carbon flux: the case of invasive beavers (Castor canadensis) in riparian Nothofagus forests of Tierra del Fuego, Chile. Clim Change 153:219-234. https://doi.org/10.1007/s10584-019-02377-x

Polis GA, Strong DR (1996) Food web complexity and community dynamics. Am Nat 147:813-846. https://doi.org/10.1086/285880

Polis GA, Power ME, Huxel GR (2004) Food webs at the landscape level. University of Chicago Press, Chicago

Pollierer M, Scheu S, Haubert D (2010) Taking it to the next level: trophic transfer of marker fatty acids from basal resource to predators. Soil Biol Biochem 42:919-925. https://doi.org/10.1016/j. soilbio.2010.02.008

Rendoll Cárcamo J, Contador T, Gañán M et al (2019) Altitudinal gradients in Magellanic sub-Antarctic lagoons: the effect of elevation on freshwater macroinvertebrate diversity and distribution. PeerJ 7:e7128. https://doi.org/10.7717/peerj.7128

Taipale SJ, Kainz MJ, Brett MT (2014) A low $\omega-3: \omega-6$ ratio in Daphnia indicates terrestrial resource utilization and poor nutritional condition. J Plankton Res 37:596-610. https://doi.org/10.1093/ plankt/fbv015

Taipale S, Strandberg U, Peltomaa E et al (2013) Fatty acid composition as biomarkers of freshwater microalgae: Analysis of 37 strains of microalgae in 22 genera and in seven classes. Aquat Microb Ecol 71:165-178. https://doi.org/10.3354/ame01671

Torres-Ruiz M, Wehr JD, Perrone AA (2007) Trophic relations in a stream food web: importance of fatty acids for macroinvertebrate consumers. J N Am Benthol Soc 26:509-522

Torres-Ruiz M, Wehr JD, Perrone AA et al (2010) Are net-spinning caddisflies what they eat? An investigation using controlled diets and fatty acids. J North Am Benthol Soc 29:803-813. https://doi. org/10.1899/09-162.1
Twining CW, Brenna JT, Hairston NG, Flecker AS (2016) Highly unsaturated fatty acids in nature: what we know and what we need to learn. Oikos 125:749-760. https://doi.org/10.1111/oik.02910

Ulloa E, Anderson CB, Ardon M et al (2012) Organic matter characterization and decomposition dynamics in sub-Antarctic streams impacted by invasive beavers. Lat Am J Aquat Res 40:881-892. https://doi.org/10.3856/vol40-issue4-fulltext-6

Valenzuela AEJ, Anderson CB, Fasola L, Cabello JL (2014) Linking invasive exotic vertebrates and their ecosystem impacts in Tierra del Fuego to test theory and determine action. Acta Oecol $54: 110-118$

Vander Zanden MJ, Casselman JM, Rasmussen JB (1999) Stable isotope evidence for the food web consequences of species invasions in lakes. Nature 401:464-467. https://doi.org/10.1038/46762

Vannote RL, Minshall GW, Cummins KW et al (1980) The river continuum concept. Can J Fish Aquat Sci 37:130-137

Volk C, Kiffney P (2012) Comparison of fatty acids and elemental nutrients in periphyton, invertebrates, and cutthroat trout (Oncorhynchus clarki) in conifer and alder streams of western Washington state. Aquat Ecol 46:85-99. https://doi.org/10.1007/s1045 2-011-9383-7

Volkman JK, Revill AT, Holdsworth DG, Fredericks D (2008) Organic matter sources in an enclosed coastal inlet assessed using lipid biomarkers and stable isotopes. Org Geochem 39:689-710. https ://doi.org/10.1016/j.orggeochem.2008.02.014

Westbrook CJ, Cooper DJ, Anderson CB (2017) Alteration of hydrogeomorphic processes by invasive beavers in southern South America. Sci Total Environ 574:183-190. https://doi.org/10.1016/j.scito tenv.2016.09.045

Whiles MR, Gladyshev MI, Sushchik NN et al (2010) Fatty acid analyses reveal high degrees of omnivory and dietary plasticity in ponddwelling tadpoles. Freshw Biol 55:1533-1547. https://doi.org/10. 1111/j.1365-2427.2009.02364.x

Publisher's Note Springer Nature remains neutral with regard to jurisdictional claims in published maps and institutional affiliations. 